\title{
Immunohistochemical Expression of Cycloxygenase-2 in Astrocytoma: Correlation with Angiogenesis, Tumor Progression and Survival
}

\author{
Astrositomalarda Siklooksijenaz 2'nin Immünobistokimyasal \\ Ekspresyonu ve Bu Ekspresyonun Angiogenesis, Tümör Yayılımı ve \\ Sağ-Kalım ile Olan İlişkisi
}

\author{
Mona EL-SAYED ${ }^{1}$, Mahmoud M TAHA $^{2}$ \\ ${ }_{1}^{1}$ Zagazig University, Faculty of Medicine, Department of Pathology, Zagazig, Egypt \\ ${ }^{2}$ Zagazig University, Faculty of Medicine, Department of Neurosurgery, Zagazig, Egypt
}

Correspondence address: Mahmoud MTAHA / E-mail: mahmoudlotfy1972@yahoo.co.uk

\begin{abstract}
AIM: Cyclooxygenase-2 (Cox-2) appears to play a role in the regulation of progression, invasiveness and angiogenesis of various neoplasms. Experimental studies have indicated that COX-2 regulate angiogenesis by modulating vascular endothelial growth factor (VEGF) production. The aim of this study was to evaluate the immunohistochemical expression of COX-2 in astrocytoma, in relation to VEGF expression, microvessel density (MVD), clinicopathologic factors and patient survival.

MATERIAL and METHODS: 26 paraffin blocks of astrocytoma, with representative tissues and sufficient follow-up data, were evaluated immunohistochemically for protein marker expression.

RESULTS: COX-2 expression was detected in 21 (80.7\%) of 26 astrocytomas with an increased expression in grade IV (100\%) as compared to grades II (63.6\%) and III (83.3\%) ( $p<0.001)$, $(r=0.64)$. A positive correlation was observed between the immunoreactive scores of COX-2, VEGF $(p<0.001),(r=0.61)$ and MVD $(p<0.001),(r=0.72)$. Also COX-2 expression was significantly associated with poor survival $(p<0.001),(r=0.58)$, but did not show significant difference among patient age, sex and tumor location.

CONCLUSION: COX-2 is up-regulated in the majority of high-grade astrocytomas and may contribute to astrocytic tumorigenesis by promoting new vessel formation. Moreover, increased COX-2 expression is a significant negative predictor of survival. COX-2 inhibitors may represent an important therapeutic target.
\end{abstract}

KEYWORDS: COX-2, VEGF, Angiogenesis, Astrocytoma

öz

AMAÇ: Siklooksijenaz 2 değişik neoplasm türlerinde tümöral yayılma, ilerleme ve yeni damar oluşumunun düzenlenmesinde etkisi vardır. Siklooksijenaz 2'nin yeni damar oluşumunu vasküler endotelyal büyüme faktörünün üretimini etkileyerek değiştirdiği deneysel çalışmalarla gösterilmiştir. Bu çalışmada, astrositomalarda Siklooksijenaz 2'nin ekspresyonu immünohistokimyasal yöntemle incelenmiş ve bu ekspresyon ile vasküler endotelyal büyüme faktörünün ekspresyonu, mikrovasküler yoğunluk, klinikpatolojik faktörler ve hasta sağkalımı arasındaki ilişki araştırılmıştır.

YÖNTEM ve GEREÇ: Astrositoma tanısı konmuş yeterli takip bilgisi olan 26 hastanın parafin blokları immünohistokimyasal yöntemler ile protein marker ekspresyonu açısından değerlendirildi.

BULGULAR: Olguların 21'inde (\%80,7), Siklooksijenaz 2ekspresyonu tesbit edildi. Siklooksijenaz 2 ekspresyonu Grade IV astrositomalarda olguların \%100'ünde, Grade III astrositomalarda olguların \%83,3'ünde, Grade II astrositomalarda olguların \%63,6'sında artmış olarak bulundu $(p<0,001)$, $(r=0,72)$. Siklooksijenazın immünoreaktif skorlaması ile vasküler endotelyal büyüme faktör arasında $(p<0,001),(r=0,61) \quad$ ve mikrovasküler damar yoğunluğu arasında pozitif ilişki saptandı $(\mathrm{p}<0,001),(\mathrm{r}=0,72)$. Ayrıca, Siklooksijenaz 2 ekspresyonu ile daha kısa süreli sağ kalım ilişki saptandı; buna göre Siklooksijenaz 2 ekspresyonu sağ kalım açısından negatif bir prediktördür( $(p<0,001),(r=0,58)$. Siklooksijenaz 2 ekspresyonu ile hasta yaşı ve tümör yerleşimi ile ilgili olarak bir ilinti saptanmamıştır.

SONUÇ: Siklooksijenaz 2 ekspresyonu yüksek dereceli astrositik tümörlerde normalden daha fazla eksprese edilmektedir (Upregulation), artmış ekspresyon yeni mikrovasküler yapıların oluşumu yolu ile tümörogenesise yol açmaktadır. Bunun yanında Siklooksijenaz 2 upregulasyonu hayatta kalım için negatif bir prediktördür, bu nedenle; tedavi açısından siklooksijenaz 2 inhibisyonu önemli bir hedef olabilir.

ANAHTAR SÖZCÜKLER: Siklooksijenaz 2, VEGF, Anjiogenesis, Astrositoma 


\section{INTRODUCTION}

Prostaglandin $\mathrm{H}$ synthetase (PGHS) or COX is the rate-limiting enzyme in the synthesis of prostaglandins and thromboxane from arachidonic acid. Two isoforms of PGHS, referred to as COX-1 and COX-2, have been described $(7,38)$. COX-2 expression is inducible and increases in response to various stimuli, including inflammatory signals, mitogens, cytokines, and growth factors $(8,19,28)$. Increased COX-2 expression was detected in a variety of human cancers, including pancreatic, gastric, esophageal, prostatic, lung and head and neck cancers $(3,16,25,35,41,43-45)$.

The astrocytic glioma is the most common primary brain tumor, accounting for more than $25 \%$ of all central nervous system neoplasm. It ranges in clinical behavior and histological appearance from indolent and well-differentiated lesions to highly anaplastic and rapidly growing tumor. For growth, neoangiogenesis is a prerequisite, and correlations between vascular proliferation and morphological changes of the neovasculature and tumor aggressiveness have been described $(12,37)$. Angiogenesis is a very complex multistep process that leads to formation of new blood vessels. It depends on the local balance between various molecules that induce and inhibit neovascularization (21), with the vascular endothelial growth factor (VEGF) thought to be a pivotal inducer of brain tumor neoangiogenesis $(17,33,34)$. It has been shown that hypoxia; hypoglycemia, hormones, growth factors, and deregulation of several genes are responsible for upregulation of VEGF expression (17). Furthermore, several studies have indicated that overexpression of COX-2 may contribute to VEGF-induced angiogenesis $(10,11)$. It has been reported that $\mathrm{COx}-2$ works on angiogenesis associated with growth and advancement of various tumors including advanced ovarian serous carcinomas, breast cancers, gastric cancers, renal cell carcinomas, head and neck squamous cell carcinoma and colon cancers $(1,4,11,15,24,39)$.

The aim of the present study was to examine the immunohistochemical expression of COX-2 in relation to VEGF and microvessel density (MVD) in astrocytomas. We also analyzed the relative importance of COX-2 immunoreactive scores with other clinicopathologic features as patient age, sex, tumor location, histopathologic grade and patient survival.

\section{MATERIAL and METHODS}

\section{Specimen collection:}

A total of 26 cases of astrocytic tumor surgically treated at Neurosurgery Department, Zagazig University Hospital during the period from September 2006 to April 2008. The clinical data of the patients were obtained from medical files. They included 14 male and 12 female patients with ages ranging from 4 to 56 years with a mean age of $35.7 \pm 18.2$. All patients were treated with surgery and radiation therapy. The survival period was determined from the date of initial surgery and median follow-up duration was $12.88 \pm 5.31$ months.

\section{Histopathological examination:}

Tumor specimens were fixed in $10 \%$ buffered formalin and embedded in paraffin. Consecutive 4 um sections were prepared and stained with hematoxylin \& eosin for histopathological examination. Pathological diagnosis of astrocytic tumor was made according to the World Health Organization (WHO) classification of brain tumors (18). The tumors comprised 15 high grade astrocytomas, including 9 glioblastomas (grade IV) and 6 anaplastic astrocytomas (grade III), as well as 11 low-grade astrocytomas (grade II) which were further subclassified into 8 fibrillary ( 3 cases had small foci of gemistocytic cells) and 3 gemistocytic subtypes. All of the 26 astrocytomas were categorized as primary type.

\section{Immunohistochemistry:}

The immunohistochemical analysis was performed on formalin fixed, paraffin embedded tissue sections using standard streptavidin-biotin-peroxidase complex (ABC) methods. Briefly, after routine deparaffinization, the five microns thick sections mounted on optiplus positivecharged adhesive slides (Biogenix Co.) were treated with $0.3 \%$ hydrogen peroxide in methanol for $30 \mathrm{~min}$ to block endogenous peroxidase activity. Sections were then washed in phosphate buffered saline (PH 7.4) and Tris-buffer solution (PH 7.6) respectively. For COX-2, VEGF and CD34, slides were microwaved for 20 minutes for antigen retrieval, and incubated overnight at $4^{\circ} \mathrm{C}$ with optimal dilutions of primary antibodies. The antibodies used were anti-COX-2 mouse monoclonal antibody (1/50 dilution; Transduction Laboratories, Lexington, KY, USA), anti-VEGF rabbit polyclonal antibody (1/50 dilution; A-20 Santa Cruz, Biotechnology, Inc, Santa Cruz, CA.), and anti-CD34 mouse monoclonal antibody (1/25 dilution; QB-END/10, Novo-castra, Newcastle, UK). Sections then treated with avidin-biotin-peroxidase reagent for 30 minutes (Dako, Japan). Lastly, sections were incubated with diaminobenzidine and counter-stained with hematoxylin then cleared and mounted. To confirm COX-2 immuno-specificity, a case of a COX-2- positive colon cancer was used as a positive control. 0.01-M phosphate-buffered saline or mouse serum (500 dilutions) was supplied instead of primary antibodies as a negative control.

\section{Assessment of COX-2 and VEGF immunoreactivity:}

Scoring of the immuno-histochemical results for COX-2 and VEGF was performed according to the methods described by Hara et al (13). Briefly, based on the proportions of immunopositive cells, five categories were defined as follows: 0 , all negative; $1+,<25 \%$ positive cells; $2+, 25-49 \%$; $3+$, 50-74\%; and 4+, $>75 \%$. The immuno-intensity was also sub classified into four groups as follows: 0 , negative; $1+$, weak; $2+$, moderate; and $3+$, strong. Positive controls were set as 3. Immunoreactivity scores for each case were produced by multiplication of the values for the two parameters. Immunoreactive scoring was categorized as low $\leq 3$ and moderate to high $\geq 4$. 


\section{Assessment of Microvessel counting (Microvessel density):}

A single microvessel was defined as any brown or brownish yellow CD34-immunostained endothelial cells. Microvessel density (MVD) was evaluated according to the method described by Ding et al (6). The entire tumor section was scanned at low magnification (40x) to identify the area of highest vessel density (hot spot). The five most vascular areas within the tumor mass were chosen. Individual microvessels in each hot spot were then counted in a single 200x field and the average counts of the 5 fields were recorded and defined as MVD. A vessel lumen was not required for identification of a microvessel. Single cells or cell clusters were counted. Large vessels with thick muscular walls or with lumina greater than 50 um were excluded from the count.

\section{Statistical analysis:}

Statistical analysis of data for labeling indices was performed using the Mann-Whitney $U$ test, Spearman's correlation coefficient, ANOVA test and the chi-square X2 test. The logrank test was performed to compare survival rates. The cut-off for statistical significance was set as $p<0.05$.

\section{RESULTS}

\section{COX-2 expression and its correlation with clinico-pathologic factors:}

Cox-2 expression was confined to the cytoplasm of tumor cells. It is expressed in nerve cell bodies, in reactive astroglial cells and rarely expressed in endothelial cells. It is consistently negative in glial cells in normal brain tissue. COX-2 expression was detected in $21(80.7 \%)$ of 26 astrocytomas. Seven (63.6\%) of low grade astrocytoma $(\mathrm{N}=11)$ had immunoreactive score $\leq 3$ (Figure 1 ) and 4 cases (36.4\%) were negative. In anaplastic astrocytoma specimens $(\mathrm{N}=6), 5$ cases $(83.3 \%)$ had immunoreactive score $\leq 3$ (Figure 2 ) and one case $(16.7 \%)$ was negative. In glioblastoma specimens $(\mathrm{N}=9), 55.6 \%(\mathrm{~N}=5)$ had immunoreactive score $\geq 4$ (Figure 3 ) and $44.4 \%(\mathrm{~N}=4)$ had immunoreactive score $\leq 3$. Although COX-2 staining was evident in cells located away from necrotic areas, accumulation of COX2-positive tumor cells was particularly conspicuous around areas of necrosis (Figure 4). The correlation between Cox-2 expression and clinicopathologic factors is shown in Table (I, II). COX-2 expression showed a stepwise increase from low-grade to high grade astrocytomas (Figure 11) which is statistically significant $(p<0.001),(r=0.64)$. However, COX-2 expression did not show significant difference among patient age, sex and tumor location ( $p>0.05$ ).

\section{VEGF expression and its correlation with clinicopathologic factors:}

VEGF expression was confined to the cytoplasm of tumor cells. It is expressed weakly in nerve cell bodies and in reactive astroglial cells and is consistently negative in glial cells in normal brain tissue. VEGF expression was detected in 22 $(84.6 \%)$ of 26 astrocytomas, including eight cases $(72.7 \%)$ of low grade astrocytoma $(\mathrm{N}=11), 5$ cases $(83.3 \%)$ of anaplastic astrocytoma specimens $(\mathrm{N}=6)$ and 9 cases $(100 \%)$ of

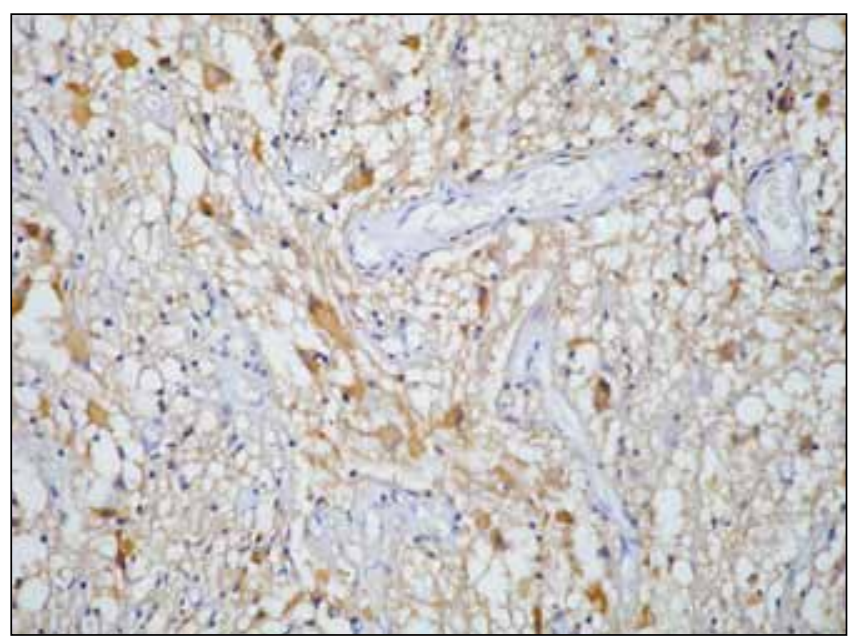

Figure 1: Low grade astrocytoma showing focal moderate cytoplasmic staining for COX2 (IP, Meyer's hematoxylin counter stain $\times 200$ ).

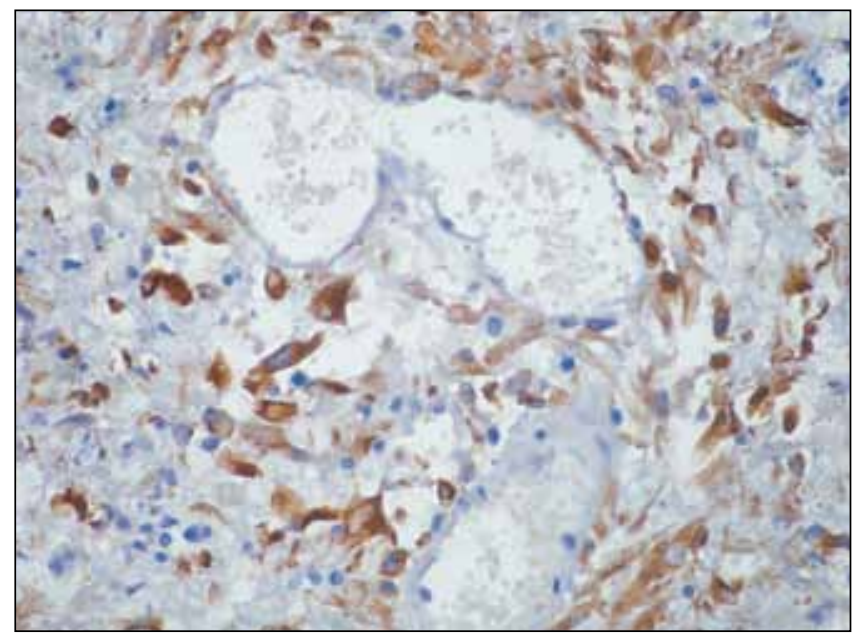

Figure 2: Anaplastic astrocytoma showing focal intense cytoplasmic staining for COX2 (IP, Meyer's hematoxylin counter stain $\times$ 400).

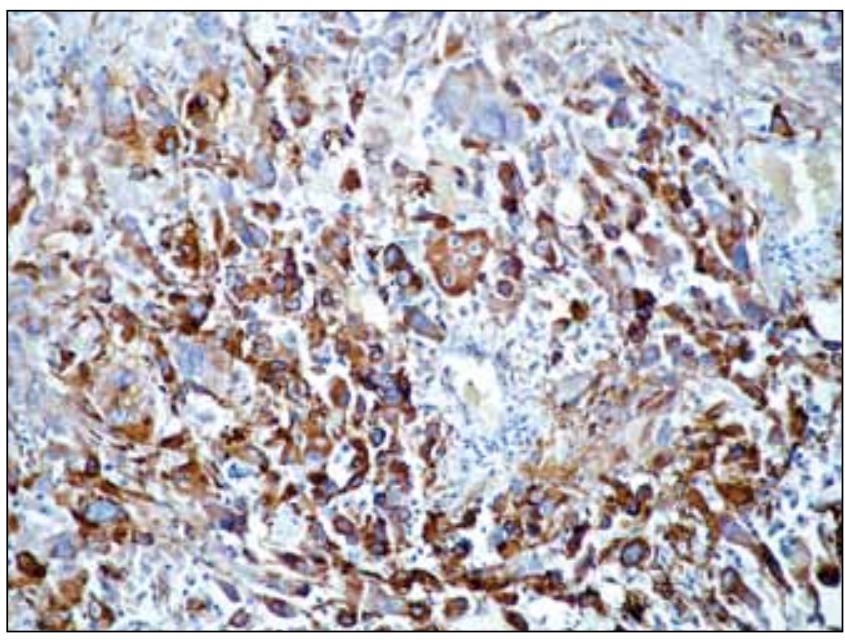

Figure 3: Glioblastoma muliforms showing focal intense cytoplasmic staining for COX2 (IP, Meyer's hematoxylin counter stain $x$ 400). 
glioblastomaspecimens $(\mathrm{N}=9)$.Inlowgradeastrocytoma, seven of the eight positive cases (87.5\%) had immunoreactive score $\leq 3$ (Figure 5) and one case (12.5\%) had an immunoreactive score $\geq 4$. In anaplastic astrocytoma specimens, 4 of the 5 positive cases (80\%) had an immunoreactive score $\leq 3$ and one case (20\%) had an immunoreactive score $\geq 4$ (Figure 6). In glioblastoma specimens, 3 of the 9 positive cases $(33.3 \%)$ had an immunoreactive score $\leq 3$ and 6 case $(66.6 \%)$ had an immunoreactive score $\geq 4$ (Figure 7). VEGF expression showed stepwise increase from low-grade to high-grade astrocytomas which is statistically significant $(p<0.001)$, but did not show significant difference among patient age, sex and tumor location ( $p>0.05$ ) as shown in Table (l).

\section{Microvesseldensityandits correlation with clinicopathologic factors:}

The positive expression of CD34 was mainly confined to the cytoplasm of vascular endothelial cells as brownish yellow

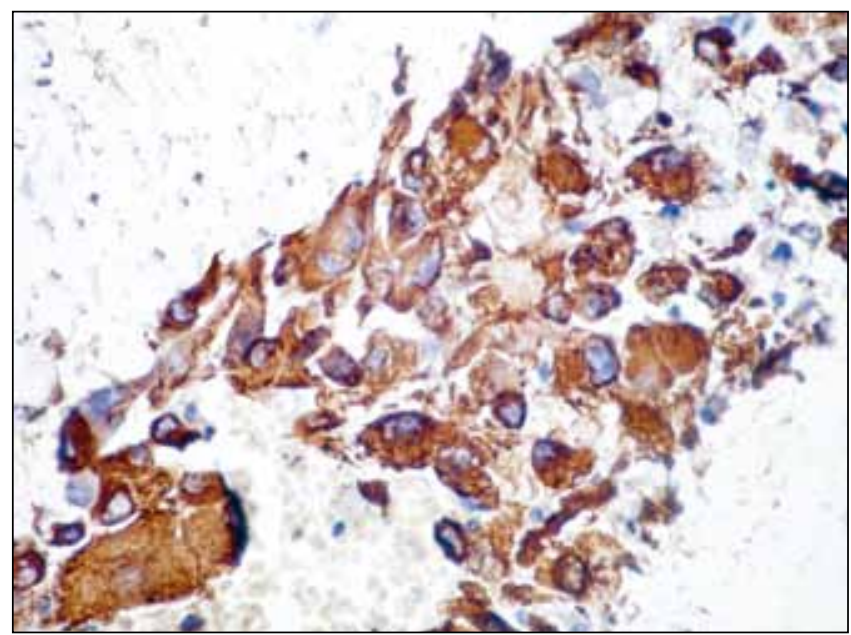

Figure 4: Glioblastoma muliforms showing focal intense cytoplasmic staining for COX2 around area of necrosis (IP, Meyer's hematoxylin counter stain $\times 400$ )

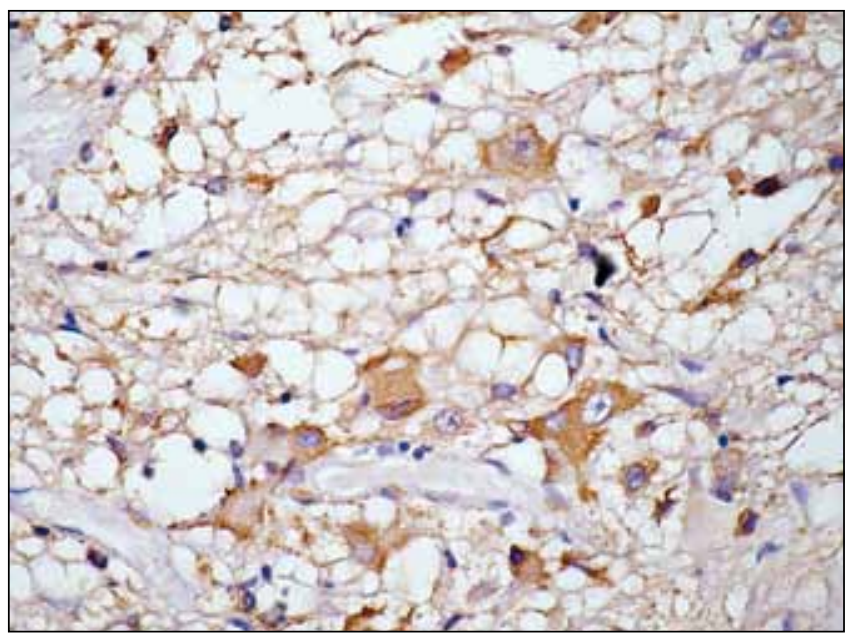

Figure 5: Low grade astrocytoma showing focal moderate cytoplasmic staining for VEGF (IP, Meyer's hematoxylin counter stain $x$ 400).

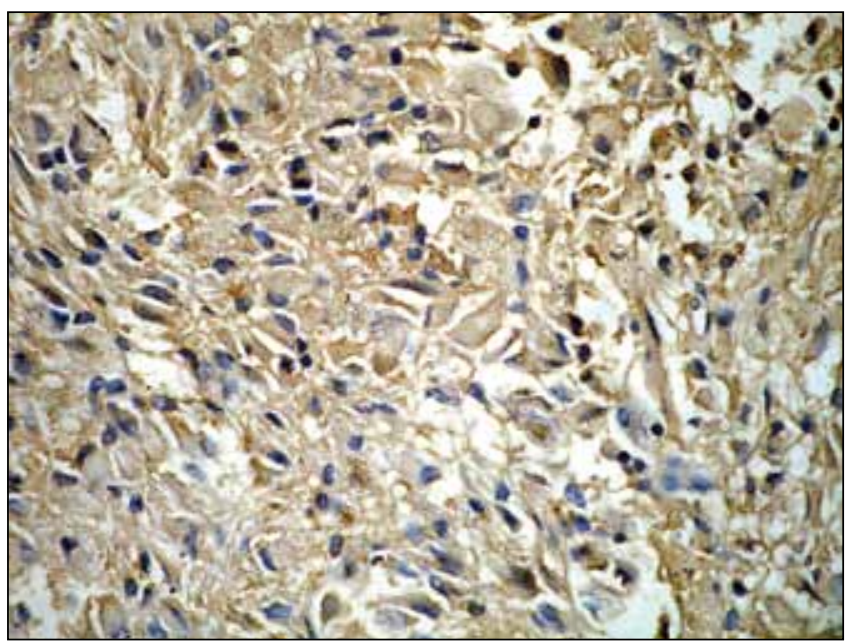

Figure 6: Anaplastic astrocytoma showing diffuse intense cytoplasmic staining for VEGF (IP, Meyer's hematoxylin counter stain $\times 400$ ).

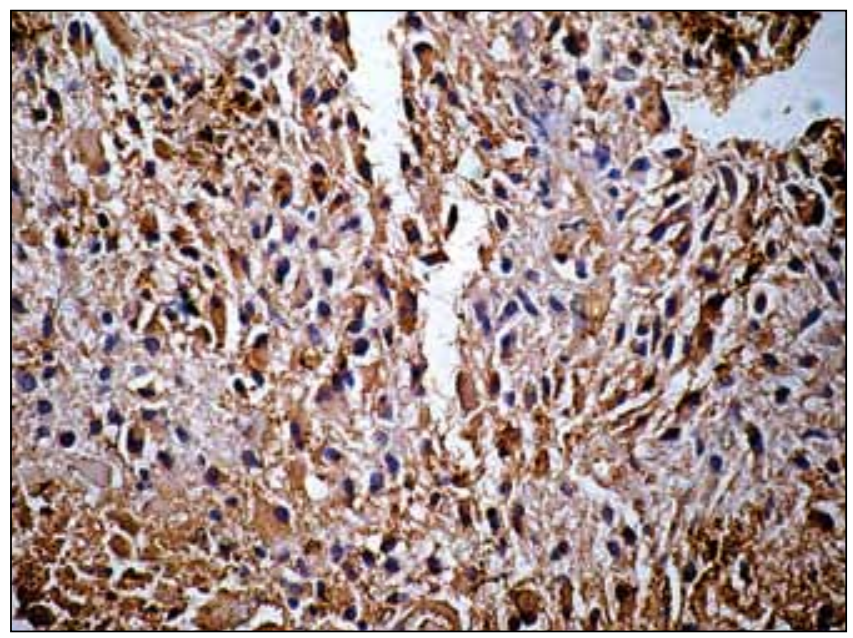

Figure 7: Glioblastoma muliforms showing focal intense cytoplasmic staining for VEGF (IP, Meyer's hematoxylin counter stain $x$ 400).

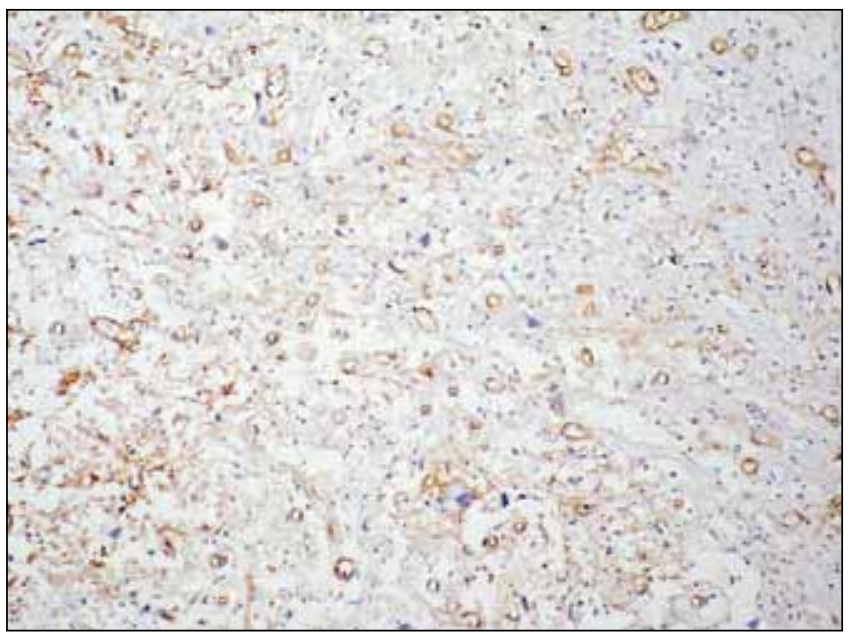

Figure 8: Immunohistochemical staining for CD34 in glioblastoma multiforme showing high microvessel density (IP, Meyer's hematoxylin counter stain $x$ 200). 
granules. Microvessels were represented by brownish yellow capillaries or small cell clusters. Astrocytomas of high grade demonstrated greater and different pattern of vascularization Figure 8,9 ) than that of low grade (Figure 10). The mean

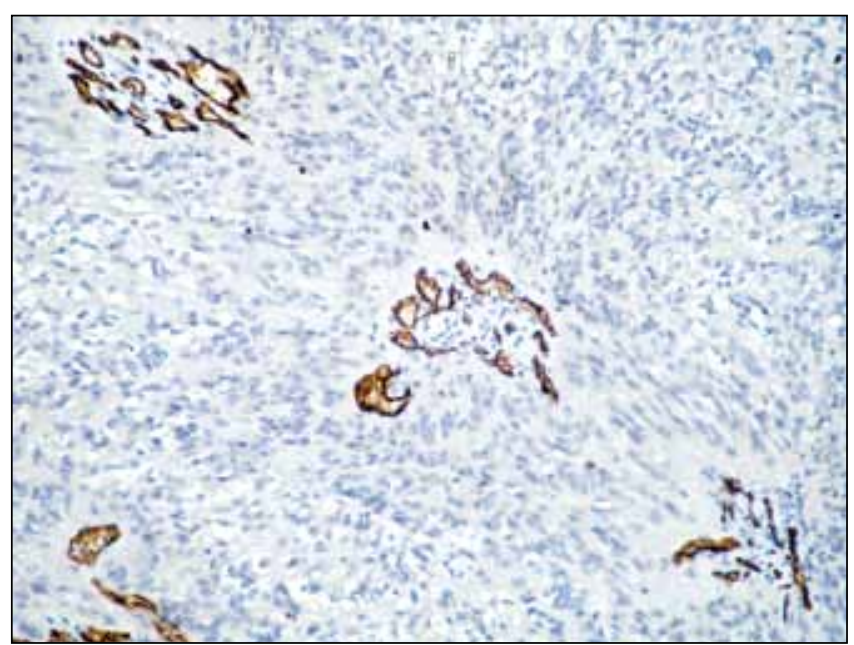

Figure 9: Immunohistochemical staining for CD34 in glioblastoma multiforme showing different pattern of microvessel density (IP, Meyer's hematoxylin counter stain x 200).
MVD values were $(5.2 \pm 5.1)$ for low grade, $(15.3 \pm 7.4)$ for anaplastic astrocytomas and $(62.4 \pm 4.5)$ in glioblastoma. MVD in astrocytomas had no significant difference among patient age, sex and tumor location ( $\mathrm{p}>0.05$ ) as shown in Table (I).

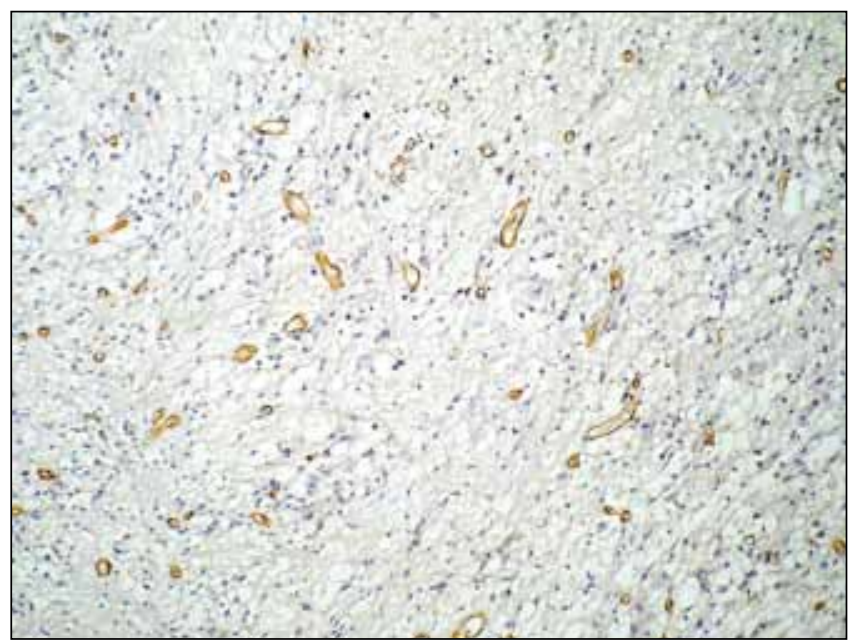

Figure 10: Immunohistochemical staining for CD34 in low grade astrocytoma showing low microvessel density (IP, Meyer's hematoxylin counter stain $\times 200$ ).

Table I: Summary of Clinicopathological Features and COX-2 Expression, VEGF Expression and MVD in Astrocytoma.

\begin{tabular}{|c|c|c|c|c|c|c|c|c|}
\hline $\begin{array}{l}\text { Age/ } \\
\text { Sex }\end{array}$ & $\begin{array}{l}\text { Tumor } \\
\text { location }\end{array}$ & $\begin{array}{l}\text { Tumor } \\
\text { grade }\end{array}$ & $\begin{array}{c}\text { COX-2 } \\
\text { expression }\end{array}$ & $\begin{array}{c}\text { VEGF } \\
\text { expression }\end{array}$ & MVD & Status & RT & $\begin{array}{l}\text { Follow-up } \\
\text { (M) }\end{array}$ \\
\hline $21 / \mathrm{F}$ & Parietal & LGA & Negative & Negative & 21 & Survival & + & 10 \\
\hline 4/M & Frontal & LGA & Negative & Negative & 17 & Survival & + & 20 \\
\hline $32 / \mathrm{M}$ & Frontoparietal & LGA & Negative & Negative & 19 & Survival & + & 23 \\
\hline 6/M & Frontoparietal & LGA & Negative & $\leq 3$ & 23 & Survival & + & 16 \\
\hline $35 / F$ & Frontoparietal & LGA & $\leq 3$ & $\leq 3$ & 29 & Survival & + & 14 \\
\hline 4/F & Frontal & LGA & $\leq 3$ & $\leq 3$ & 26 & Survival & + & 21 \\
\hline 1/F & Frontal & LGA & $\leq 3$ & $\leq 3$ & 22 & Survival & + & 20 \\
\hline $15 / F$ & Parietal & LGA & $\leq 3$ & $\leq 3$ & 27 & Survival & + & 13 \\
\hline $43 / \mathrm{M}$ & Temporal & LGA & $\leq 3$ & $\leq 3$ & 31 & Survival & + & 17 \\
\hline $36 / \mathrm{M}$ & Frontoparietal & LGA & $\leq 3$ & $\leq 3$ & 29 & Survival & + & 14 \\
\hline $51 / \mathrm{M}$ & Temporal & LGA & $\leq 3$ & $\leq 3$ & 33 & Survival & + & 15 \\
\hline $48 / \mathrm{M}$ & Frontoparietal & $\mathrm{AA}$ & Negative & Negative & 43 & Survival & + & 16 \\
\hline $37 / F$ & Frontal & AA & $\leq 3$ & $\leq 3$ & 48 & Survival & + & 9 \\
\hline $53 / \mathrm{M}$ & Parietal & $A A$ & $\leq 3$ & $\leq 3$ & 57 & Survival & + & 18 \\
\hline $64 / F$ & Frontoparietal & AA & $\leq 3$ & $\leq 3$ & 51 & Death & + & 12 \\
\hline $32 / \mathrm{M}$ & Frontal & AA & $\leq 3$ & $\leq 3$ & 46 & Survival & + & 8 \\
\hline $49 / \mathrm{M}$ & Frontoparietal & $\mathrm{AA}$ & $\leq 3$ & $\geq 4$ & 63 & Death & + & 18 \\
\hline $39 / F$ & Parietal & GBM & $\geq 4$ & $\geq 4$ & 66 & Death & + & 8 \\
\hline $43 / F$ & Parietal & GBM & $\leq 3$ & $\leq 3$ & 56 & Death & + & 10 \\
\hline $56 / F$ & Temporal & GBM & $\geq 4$ & $\geq 4$ & 67 & Death & + & 6 \\
\hline $24 / M$ & Temporal & GBM & $\geq 4$ & $\geq 4$ & 64 & Death & + & 7 \\
\hline $29 / F$ & Frontal & GBM & $\leq 3$ & $\leq 3$ & 57 & Survival & + & 6 \\
\hline $47 / M$ & Parietal & GBM & $\geq 4$ & $\geq 4$ & 61 & Death & + & 4 \\
\hline $46 / F$ & Frontal & GBM & $\leq 3$ & $\leq 3$ & 59 & Survival & + & 11 \\
\hline $61 / M$ & Parietal & GBM & $\geq 4$ & $\geq 4$ & 63 & Death & + & 13 \\
\hline $57 / M$ & Temporal & GBM & $\geq 4$ & $\geq 4$ & 69 & Death & + & 6 \\
\hline
\end{tabular}

Abbreviations : $\mathbf{L G A}$; low grade astrocytoma, $\boldsymbol{A A}$; anaplastic astrocytoma $\mathbf{G B M}$; glioblastoma, $\boldsymbol{R T}$; radiotherapy 


\section{Correlation between Cox-2 expression, VEGF expression and MVD:}

Immunoreactive scores of VEGF positive cells were significantly increased in Cox-2 positive tumors compared with Cox-2 negative one $(p<0.001),(r=0.61)$ as shown in Table (III) and (Figure 12). Almost all of the Cox-2 negative tumors exhibited negative staining of VEGF except in one case. COX-2 expression was significantly correlated with MVD $(p<0.001)$, $(r=0.72)$. The mean MVD in Cox-2 positive astrocytomas with immunoreactive scores $\geq 4$ was significantly higher

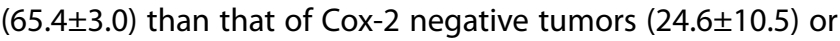
with immunoreactive scores $\leq 3(43.6 \pm 14.9)$ as shown in Table (IV) and (Figure 13). VEGF expression was also significantly correlated with MVD $(p<0.001)$.

\section{Correlation between Cox-2 and patient survival:}

Mean follow-up duration in COX-2 positive astrocytomas with immunoreactive scores $\geq 4$ and with immunoreactive scores $\leq 3$ was $7.33 \pm 3.08$ and $13.73 \pm 4.48$ respectively, while mean follow-up duration in COX-2 negative astrocytomas was $17 \pm 4.9$. COX-2 expression was significantly correlated with poor survival $(p<0.001),(r=0.58)$ as shown in Table $(V)$ and (Figure 14).

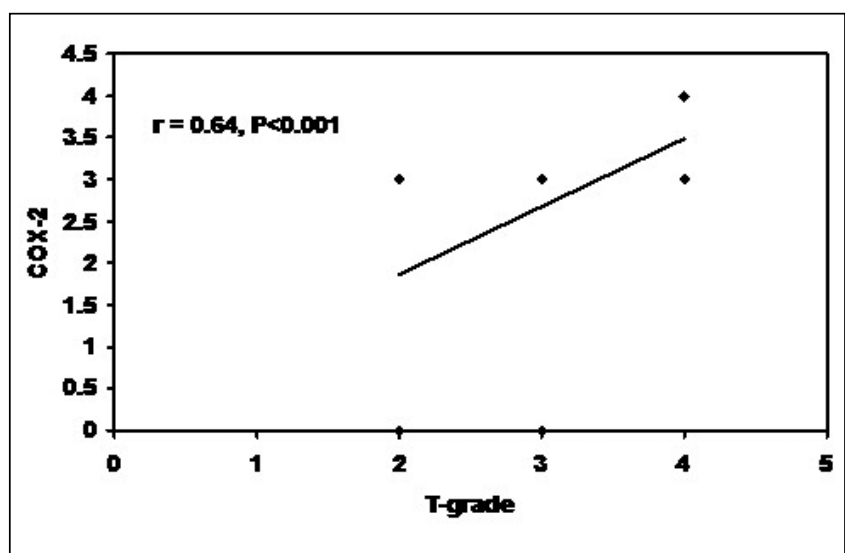

Figure 11: Correlation between COX-2 expression and histopathologic grade in astrocytoma.

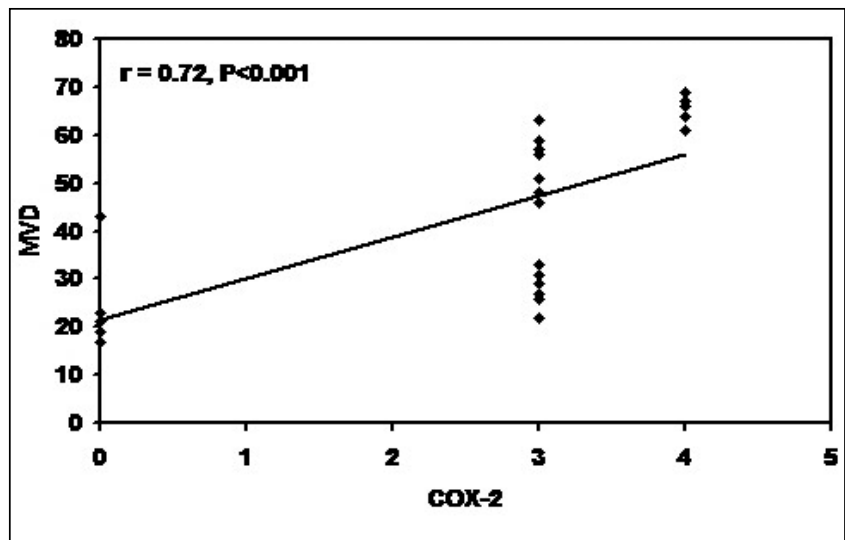

Figure 13: Correlation between the immunoreactivity score among COX-2 and MVD in astrocytoma.

\section{DISCUSSION}

Many glioblastomas, the most malignant type of gliomas, are believed to arise by progression from low-grade astrocytomas and anaplastic astrocytomas (35). However, the molecular mechanisms underlying the malignant phenotype and progression are not clear (2). There are some suggestions that COX-2 may be involved in the regulation of progression, invasiveness and angiogenesis of various neoplasms (27). Whereas experimental studies have indicated that COX-2 regulates angiogenesis by modulating VEGF production (22), little is known about the relationships among expression of these markers.

In the present study, COX-2 expression was detected in $21(80.7 \%)$ of 26 astrocytomas. This incidence is slightly lower than that obtained by Shono et al, (35), Lee et al, (20) and Marina et al, (22) who detected COX-2 expression in $84 \%$, $100 \%$ and $95 \%$ respectively. In the study of Perdiki et al COX-2 expression was detected in 79 cases (95\%) with an increased expression in grade IV as compared to grades II/III (29). On the other hand, our incidence is higher than that obtained by Yamen et al. (36) in which COX-2 expression was detected in $49 \%$ of astrocytomas. The discrepancies observed in these

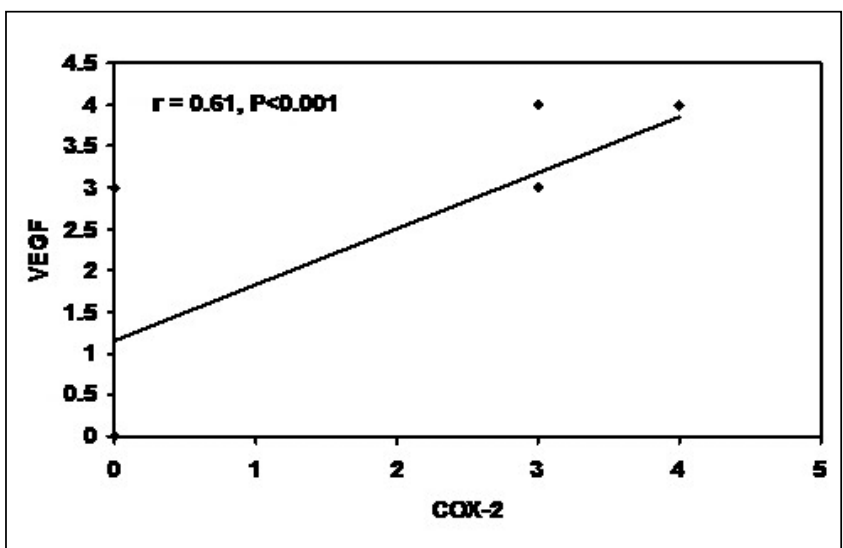

Figure 12: Correlation between the immunoreactivity scores among COX-2 and VEGF in astrocytoma.

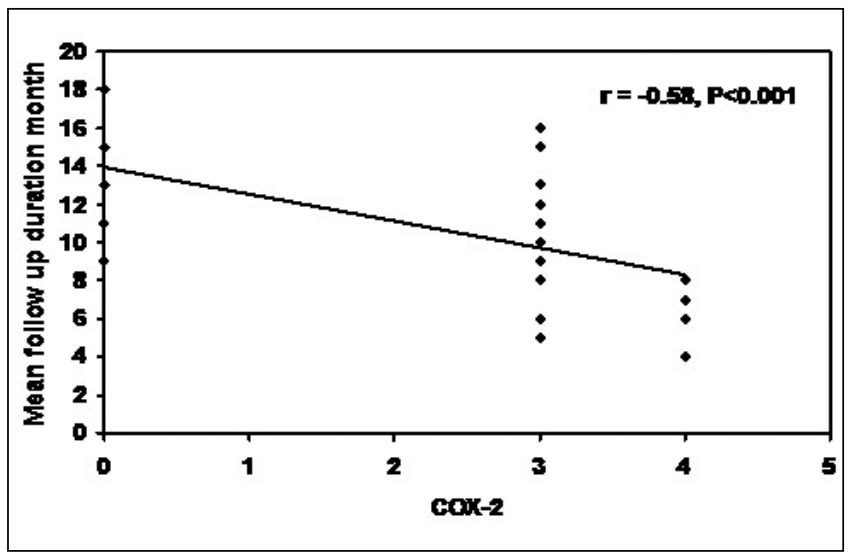

Figure 14: Correlation between the immunoreactivity score among COX-2 and mean follow- up duration in astrocytoma. 
Table II: Correlation between COX-2 Expression and Histopathologic Grade in Astrocytoma

\begin{tabular}{|c|c|c|c|c|}
\hline \multirow{3}{*}{$\begin{array}{l}\text { Tumor } \\
\text { grade }\end{array}$} & \multirow{3}{*}{$\begin{array}{c}\text { Total } \\
\text { number }\end{array}$} & \multicolumn{2}{|c|}{ COX-2 expression } & \\
\hline & & \multirow[t]{2}{*}{$\begin{array}{c}\text { Negative } \\
\text { No } \%\end{array}$} & \multicolumn{2}{|c|}{$\begin{array}{c}\text { Positive } \\
\leq 3 \geq 4\end{array}$} \\
\hline & & & No \% & No \% \\
\hline Low grade (11) & 11 & 436.4 & 7 & 63.6 \\
\hline Anaplastic (111) & 6 & 116.7 & 5 & 83.3 \\
\hline Glioblastoma (1v) & 9 & 00 & 444.4 & 555.6 \\
\hline
\end{tabular}

COX-2 expression was significantly correlated with tumor grade $(r=0.64),(p<0.001)$

Table III: Correlation between the Immunoreactivity Scores among COX-2 and VEGF in Astrocytoma

\begin{tabular}{c|c|r|r}
$\begin{array}{c}\text { Total } \\
\text { number }\end{array}$ & Immunoreactivity & COX-2 expression & VEGF expression \\
No \%
\end{tabular}

COX-2 expression was significantly correlated with VEGF $(r=.61),(p<0.001)$

Table IV: Correlation between the Immunoreactivity Score Among COX-2 and MVD in Astrocytoma

\begin{tabular}{|c|c|c|c|}
\hline $\begin{array}{c}\text { Total } \\
\text { number }\end{array}$ & Immunoreactivity & $\begin{array}{c}\text { COX-2 expression } \\
\text { No } \%\end{array}$ & $\begin{array}{c}\text { MVD } \\
\text { Mean } \pm \text { SD }\end{array}$ \\
\hline 26 & $\begin{array}{c}\text { Negative } \\
\text { Positive with IRS } \leq 3 \\
\text { Positive with } I R S \geq 4\end{array}$ & $\begin{array}{r}519.2 \\
1661.5 \\
519.2\end{array}$ & $\begin{array}{c}24.6 \pm 10.5 \\
43.6 \pm 14.9 \\
65.4 \pm 3.0\end{array}$ \\
\hline
\end{tabular}

COX-2 expression was significantly correlated with MVD $(r=0.72),(p<0.001), S D=$ standard deviation

Table V: Correlation between the Immunoreactivity Score among COX-2 and Mean follow- up Duration in Astrocytoma

\begin{tabular}{c|c|c|c}
\multicolumn{1}{c}{$\begin{array}{c}\text { Total } \\
\text { number }\end{array}$} & $\begin{array}{c}\text { COX-2 expression } \\
\text { No \% }\end{array}$ & $\begin{array}{c}\text { Mean follow- up duration } \\
\text { (M) }\end{array}$ \\
\multirow{2}{*}{26} & Negative & 519.2 & $13.2 \pm 3.5$ \\
& Positive with IRS $\leq 3$ & 1661.5 & $10.56 \pm 3.5$ \\
& Positive with IRS $\geq 4$ & 519.2 & $6.2 \pm 4.482$ \\
\hline
\end{tabular}

COX-2 expression was significantly correlated with poor survival $(r=0.58),(p<0.001)$

results may be related to patient selection bias and lack of standard immunohistochemical assays, including different properties of the antibodies and assessment methods of COX2 immunoreactivity.

In our study, COX-2 expression showed significant stepwise increase from low-grade (63.6\%) to high grade astrocytomas including anaplastic astrocytoma (83.3\%) and glioblastoma specimens (100\%). The positive association between the extent of COX-2 expression and histopathologic grade of astrocytic gliomas is consistent with that reported in other studies $(13,14,20,26,35)$. These observations support the hypothesis that COX-2 protein may play a relevant role in malignant change during astrocytic tumorigenesis. Although the mechanisms remain unclear, an in vitro study indicated that overexpression of COX-2 results in dedifferentiation, adhesion to extracellular matrices, and inhibition of programmed cell death in intestinal cells (11). There are some suggestions that COX-2 may be involved with modulating several tumor related processes. Subbaramaiah et al. (36) noted that the wild type of tumor suppressor p53 gene might be responsible in part for inhibiting COX-2 gene expression, while increased amounts of bcl-2 protein were correlated with increased COX-2 expression. Epidermal growth factor (EGF) is known to up-regulate the expression of the COX-2 enzyme in several cell types, such as human squamous carcinoma cells. Among the genetic change that are commonly observed in 
glioblastomas and that seem to be specific for this tumor stage are loss of heterozygosity of chromosome 10 along with EGF receptor up-regulation that may be one of the factors that contributed to the up-regulation of $\operatorname{COX}-2(9,29,40)$.

Consistent with the findings of Onguru et al (27), Joki et al. (14) and Deininger et al. (5), we observed significant COX-2 staining within astrocytic tumor cells located predominantly but not exclusively around areas of necrosis. This distribution may represent induction of COX-2 by hypoxia or hypoglucosemia, as has been observed for ischemia $(31)$ and trauma $(16,23)$ and is consistent with the inducibility of COX-2. However, we also observed COX-2 staining at sites without necrosis, suggesting that COX-2 may be constitutively expressed in tumor cells. We did not observe any COX-2 staining in the nuclei of tumor cells as that reported by Shono et al (35). Its significance is unclear, but this observation may represent the known distribution of COX-2 within the nuclear membrane. COX-2 expression did not show significant difference among patient age, sex and tumor location as observed by Shono et al. (35) and Lee et al (20).

In the present study, we found a significant positive correlation between COX-2 expression and the angiogenetic factor VEGF expression and MVD in astrocytomas. Our results are supported by previous reports of Hara et al. (13) and Marina et al. (22), who found a strong correlation among the expression of these markers in astrocytomas. Tsuji et al. (39) demonstrated that COX-2 stimulates colon cancer cells to release pro-angiogenic PGs that promote endothelial cell migration and tube formation, and these effects can be blocked by NS-398, a selective inhibitor of COX-2. Samaras and others reported that the coordinate expression and topographical relationship of IL-6, IL-8, COX-2, and VEGF in the same tumor areas (e.g., perinecrotic areas) attest to their intimate liaison in terms of cancer-induced angiogenesis, which is probably secondary to the induction of multiple interdependent molecular pathways (32). Moreover, Majima et al. (21) considered endogenous PGs might increase cAMPfacilitated angiogenesis through induction of VEGF in a rat sponge implantation model. These data suggest that COX-2 participates in the induction of VEGF or, alternatively, COX-2 and VEGF may have a common induction pathway. On the other hand, Onguru et al. (27), found no correlation between COX-2 expression and MVD in glioblastomas.

In the present study, COX-2 overexpression was significantly correlated with poor survival. Several studies have similarly provided evidence of a relationship between shortened survival and elevated COX-2 expression (13, 20, 22, 35).

Sawaoka et al. (31) have demonstrated that oral administration of specific COX-2 inhibitors lowered the expression of VEGF, reduced angiogenesis and growth, induced apoptosis, and suppressed cell replication of the COX-2 overexpressing gastrointestinal cancer xenografts in a dose-dependent manner. Joki et al. (14), demonstrated that NS-398, a COX-2 specific inhibitor, can increase apoptosis, reduce proliferation, and attenuate invasion of cultured human glioma cells. This indicates that COX-2 inhibitors may represent an important therapeutic target in the treatment of astrocytomas, particularly if the selective COX-2 inhibitor can cross the blood brain barrier.

In conclusion, a stepwise increase in COX-2 expression from low grade to high grade astrocytomas might suggest the role of COX-2 in tumor progression. The close correlation between COX-2 expression, VEGF expression and MVD, raises the possibility that the COX-2 pathway may contribute to astrocytic tumorigenesis by promoting new vessel formation. Increased COX-2 expression is a significant negative predictor of survival in astrocytic tumors. This will help to establish a comprehensive therapeutic measure of patients and provide a new approach to tumor therapy through COX-2 inhibitors. We join Perdiki and his colleagues (29) and call for further studies to investigate the clinical usefulness of COX-2 inhibitors in the treatment of astrocytoma.

\section{REFERENCES}

1. Ali-Fehmi R, Che M, Khalifeh I, Malone JM, Robert M, Lawrence WD, Munkarah AR: The effect of cyclooxygenase-2 expression on tumor vascularity in advanced stage ovarian serous carcinoma. Cancer 98: 1423 -1429, 2003

2. Burger PC, Vogel FS, Green SB, Strike TA: Glioblastoma multiforme and anaplastic astrocytoma. Pathologic criteria and prognostic implications. Cancer 56: 1106-1111, 1985

3. Chan G, Boyle JO, Yang EK, Zhang F, Sacks PG, Shah JP, Edelstein D, Soslow RA, Koki AT, Woerrer BM, Mosferrer JL, Dannenberg AJ: Cyclooxygenase -2 expression is up-regulated in squamous cell carcinoma of the head and neck. Cancer Res 59: 991-994, 1999

4. Davies G, Salter J, Hills M, Martin LA, Sacks N, Dowsett M. Yang $H Y$, Yang L: Correlation between cyclooxygenase- 2 expression and angiogenesis in human breast cancer. Clin Cancer Res 9: 2651-2656, 2003

5. Deininger $\mathrm{MH}$, Weller $\mathrm{M}$, Streffer J, Mittelbronn M, Meyermann R: Patterns of cyclooxygenase-1 and -2 expression in human gliomas in vivo. Acta Neuropathol (Berl) 98: 240-244, 1999

6. Ding Y, Chen G, Xia J, Zang XW: Association of VCAM1overexpression with oncogenesis and metastasis of gastric carcinoma. World J Gastroenterol 9 (7): 1409-1414, 2003

7. DuBois RN, Abramson SB, Crofford L, Gupta R, Simon L, Van De Pantle L, Lipsky PC, Faseb J: Cyclooxygenase in biology and disease. FASEB J 12: 1063-1073, 1998

8. DuBois RN, Awad J, Morrow J, Roberts LJ, Bishop PR: Regulation of eicosanoid production and mitogenesis in rat intestinal epithelial cells by transforming growth factor- and phorbol ester. J Clin Investig 93: 493-498, 1994

9. Fujimoto $M$, Fults DW, Thomas GA, Nakamura $Y$, Heilbrun MP, White R, Story JL,Naylors L, Kagan-Hallet KS, Sheridan PJ: Loss of heterozygosity on chromosome 10 in human glioblastoma multiforme. Genomics $4: 210-214,1989$

10. Fujiwaki R, Lida K, Kawasaki H, Ozaki T, Hata K, Miyazaki K: Cyclooxygenase-2 expression in endometrial cancer: Correlation with micro-vessel count and expression of vascular endothelial growth factor and thymidine phosphorylase. Human Pathol 33:213-219, 2002

11. Gallo O, Masini E, Bianchi B, Brushini L, Paglerani M, Franchi A: Prognostic significance of cyclo-oxygenase-2 pathway and angiogenesis in head and neck squamous cell carcinoma. Human Pathol 33:708-714, 2002 
12. Hanahan D, Folkman J: Patterns and emerging mechanisms of the angiogenic switch during tumorigenesis Cell 86: 353-356, 1996

13. Hara A, Okayasu I: Cyclooxygenase-2 and inducible nitric oxide synthase expression in human astrocytic gliomas: correlation with angiogenesis and prognostic significance. Acta Neuropathol 108: 43-48, 2004

14. Joki T, Heese O, Nikas DC, Bello L, Zhang J, Kraeft S, Seyfried NT, Abe T, Chen LB, Carroll RS, Black PM: Expression of cyclooxygenase-2 in human glioma and in vitro inhibition by a specific COX-2 inhibitor, NS-398. Cancer Res 60: 4926-4931, 2000

15. Joo YE, Rew JS, Seo YH, Choi SK, Kim YJ, Park CS, Kim SJ: Cyclooxygenase-2 overexpression correlates with vascular endothelial growth factor expression and tumor angiogenesis in gastric cancer. J Clin Gastroenterol 37: 28-33, 2003

16. Kang HC, Xu F, Liu XY, Hu Q, Liu Y, Tang K, Li X, Wang Y, Liu ZG, Zhu SQ: Brain injury in adenosine $A 1$ receptor knock-out mice after pentetrazole kindling and its correlation with COX-2. Zhonghua Yi Xue Za Zhi 89(37):2634-2638, 2009

17. Kieser A, Weich $H$, Brandner G: Mutant p53 potentiates protein kinase $C$ induction of vascular endothelial growth factor expression. Oncogene 9:963-969, 1994

18. Kleihues $P$, Cavenee WK: Pathology and genetics of tumours of the nervous system. Lyon: IARC Press, 2000:29-39

19. Kujubu DA., Fletcher BS, Varnum BC, Lim RW, Herschman HR: TIS10, a phorbol ester tumor promoter-inducible mRNA from Swiss 3T3 cells, encodes a novel prostaglandin synthase /cyclooxygenase homo-logue. J Biol Chem 266: 12866-12872, 1991

20. Lee JM, Jung S, Rhu HH, Kim IY, Lee MC: Cyclooxygenase-2 expression predicts Prognosis in astrocytic tumors. J Korean Neurosurg Soc 36: 437-442, 2004

21. Majima M, Amano $H$, Hayashi I: Angiogenic and prostaglandin. Folia Pharmacol Jpn 117:283-292, 2001

22. Marina P, Penelope $K$, Irene T: Cyclooxygenase-2 expression in astrocytomas. Relationship with micro-vascular parameters, angiogenetic factors expression and survival. J Molecular and Cellular Biochemistry 295: 75 - 83, 2007

23. Miettinen S, Fusco F R, Yrjanheikki J, Keinanen R, Hirvonen T, Roivainen R, Narthi M, Hokfelt T, Koistinaho J: Spreading depression and focal brain ischemia induce cyclooxygenase-2 in cortical neurons through $\mathrm{N}$-methyl-D-aspartic acid-receptors and phosphor-lipase A2. Proc Natl Acad Sci USA 94: 6500-6505, 1997

24. Miyata $Y$, Koga S, Kanda S, Nishikido M, Hayashi T, Kanetake $\mathrm{H}$ : Expression of cyclooxygenase-2 in renal cell carcinoma: Correlation with tumor cell proliferation, apoptosis, angiogenesis, expression of matrix metalloproteinase-2, and survival. Clin. Cancer Res 9: 1741-1749, 2003

25. Molina MA, Sitja-Arnau M, Lemoine MG, Frazier ML, Sinicrope FA: Increased cyclooxygenase-2 expression in human pancreatic carcinomas and cell lines: Growth inhibition by nonsteroidal antiinflammatory drugs. Cancer Res 59: 4356-4362, 1999

26. Murakami H, Sawa H, Kamada H: Expression of cyclooxygenase (COX)-2 in astrocytic tumors and antitumor effects of selective COX-2 inhibitors. Brain Nerve 58:43-49 (Abstract), 2006

27. Onguru O, Gamsizkan M, Ulutin C, Gunhan O: Cyclooxygenase-2 (Cox-2) expression and angiogenesis in glioblastoma. Neuropathology 28: 29-34, 2008

28. Pairet M, Engelhardt G: Distinct isoforms (COX-1 and COX-2) of cyclooxygenase: Possible physiological and therapeutic implications. Fundam Clin Pharmacol 10: 1-17, 1996
29. Perdiki M, Korkolopoulou P, Thymara I, Agrogiannis G, Piperi C, Boviatsis E, Kotsiakis X, Angelidakis D, Diamantopoulou K, Thomas-Tsagli E, Patsouris E: Cyclooxygenase-2 expression in astrocytomas. Relationship with microvascular parameters, angiogenic factors expression and survival. Mol Cell Biochem 295 (1-2): 75-83, 2007

30. Rasheed BK, Fuller GN, Friedman AH, Bigner DD, Bigner SH: Loss of heterozygosity for $10 \mathrm{q}$ loci in human gliomas. Genes chromosomes. Cancer 5: 75-82, 1992

31. Sairanen $T$, Ristimaki $A$, Karjalainen-Lindsberg $M L$, Paetau $A$, Kaste M, Lindsberg PJ: Cyclooxygenase-2 is induced globally in infarcted human brain. Ann Neurol 43: 738-747, 1998

32. Samaras V, Piperi C, Levidou G, Zisakis A, Kavantzas N, Themistocleous MS, Boviatsis El, Barbatis C, Lea RW, Kalofoutis A, Korkolopoulou P: Analysis of interleukin (IL)-8 expression in human astrocytomas: Associations with IL-6, cyclooxygenase-2, vascular endothelial growth factor, and microvessel morphometry. Human Immunol 70(6):391-397, 2009

33. Sawada T: Angiogenic factor of brain tumor. No-Shinkei 51: 404-410, 1999

34. Sawaoka H, Tsuji S, Tsuji M, Edhi S, Sasaki Y, Kawano S, Hori M: Cyclooxygenase inhibitors suppress angiogenesis and reduce tumor growth in vivo. Lab Invest 79:1469-1478, 1999

35. Shono T, Tofilon PJ, Bruner JM, Owolabi O, Lang FF: Cyclooxygenase-2 expression in human gliomas: Prognostic significance and molecular correlations. Cancer Res 61:43754381, 2001

36. Subbaramaiah K, Altorki N, Chung WJ, Mestre JR, Sampat A, Dannenberg AJ: Inhibition of cyclo-oxygenase-2 gene expression by p53. J Biol Chem 274 : 10911-10915, 1999

37. Takekawa Y, Sawada T, Sakurai I: Neovascular basement membrane and its significance in the biological behavior of astrocytic tumors. Neuropathology 17:196-200, 1997

38. Taketo MM: Cyclo-oxygenase-2 nhibitors in tumorigenesis (part I). J Natl Cancer Inst (Bethesda) 90: 1529-1536, 1998

39. Tsuji M, Kawano S, Tsuji S, Sawaoka H, Hori M, DuBois R: Cyclooxygenase regulates angio-genesis induced by colon cancer cells. Cell 93:705-716, 1998

40. Von Deimling A, Louis DN, von Ammon K, Louis DN, von Ammon K, Petersen I, Hoell T, Chung RY, Martuza RL, Schoenfeild DA, Yasargil MG, Wiestler OD, et al: Association of epidermal growth factor receptor gene amplification with loss of chromosome 10 in human glioblastoma multiforme. J Neurosurg 77: 295-301, 1992

41. Wardlaw SA, March TH, Belinsky SA:Cyclooxygenase-2 expression is abundant in alveolar type II cells in lung cancer-sensitive mouse strains and in premalignant lesions. Carcinogenesis (Lon) 21: 1371-1377, 2000

42. Yamin R, tong-yu C: Expression and significance of HIFa, COX-2 and VEGF proteins in glioma. Modern oncology 14 (2): (Abstract), 2006

43. Yip-Schneider MT, Barnard DS, Billings SD, Cheng L, Heilman DK, Lin A, Marshall SJ, Crowell PL, Marshall MS, Sweeney CJ: Cyclooxygenase-2 expression in human pancreatic adenocarcinomas. Carcinogenesis (Lon) 21: 139-146, 2000

44. Yoshimura R, Sano $H$, Masuda C, Kawamura M, Tsubouchi Y, Charqui J, Yoshimura N, Hla T, Wada s: Expression of cyclooxygenase-2 in prostate carcinoma. Cancer (Phila) 89: 589-596, 2000

45. Zimmermann KC, Sarbia M, Weber AA, Borchard F, Gabbert H E, Schror K: Cyclooxygenase-2 expression in human esophageal carcinoma. Cancer Res 59: 198-204, 1999 